

\section{PROOF GOVER SHEET}

Author(s): $\quad$ Laurent Milesi

Article title: SÉANCE TENANTE: Deconstruction in (the) Place of Ethics Now

Article no: $\quad$ TPAR 988908

Enclosures: 1) Query sheet

2) Article proofs

Dear Author,

1. Please check these proofs carefully. It is the responsibility of the corresponding author to check these and approve or amend them. A second proof is not normally provided. Taylor \& Francis cannot be held responsible for uncorrected errors, even if introduced during the production process. Once your corrections have been added to the article, it will be considered ready for publication.

Please limit changes at this stage to the correction of errors. You should not make trivial changes, improve prose style, add new material, or delete existing material at this stage. You may be charged if your corrections are excessive (we would not expect corrections to exceed 30 changes).

For detailed guidance on how to check your proofs, please paste this address into a new browser window: http://journalauthors.tandf.co.uk/production/checkingproofs.asp

Your PDF proof file has been enabled so that you can comment on the proof directly using Adobe Acrobat. If you wish to do this, please save the file to your hard disk first. For further information on marking corrections using Acrobat, please paste this address into a new browser window: http://journalauthors.tandf.co.uk/production/ acrobat.asp

2. Please review the table of contributors below and confirm that the first and last names are structured correctly and that the authors are listed in the correct order of contribution. This check is to ensure that your name will appear correctly online and when the article is indexed.

\begin{tabular}{|c|c|c|c|c|}
\hline Sequence & Prefix & Given name(s) & Surname & Suffix \\
\hline 1 & & Laurent & Milesi & \\
\hline
\end{tabular}


Queries are marked in the margins of the proofs, and you can also click the hyperlinks below.

\section{AUTHOR QUERIES}

\section{General points:}

1. Permissions: You have warranted that you have secured the necessary written permission from the appropriate copyright owner for the reproduction of any text, illustration, or other material in your article. Please see http://journalauthors.tandf.co.uk/permissions/ usingThirdPartyMaterial.asp.

2. Third-party content: If there is third-party content in your article, please check that the rightsholder details for re-use are shown correctly.

3. Affiliation: The corresponding author is responsible for ensuring that address and email details are correct for all the co-authors. Affiliations given in the article should be the affiliation at the time the research was conducted. Please see http://journalauthors.tandf.co.uk/preparation/ writing.asp.

4. Funding: Was your research for this article funded by a funding agency? If so, please insert 'This work was supported by <insert the name of the funding agency in full $>$ ', followed by the grant number in square brackets '[grant number $\mathrm{xxxx}]$ '.

5. Supplemental data and underlying research materials: Do you wish to include the location of the underlying research materials (e.g. data, samples or models) for your article? If so, please insert this sentence before the reference section: 'The underlying research materials for this article can be accessed at $<$ full link $>$ / description of location [author to complete]'. If your article includes supplemental data, the link will also be provided in this paragraph. See < http://journalauthors.tandf.co.uk/ preparation/multimedia.asp $>$ for further explanation of supplemental data and underlying research materials.

No Author Queries 


\section{How to make corrections to your proofs using Adobe Acrobat/Reader}

Taylor \& Francis offers you a choice of options to help you make corrections to your proofs.

Your PDF proof file has been enabled so that you can edit the proof directly using Adobe Acrobat/Reader. This is the simplest and best way for you to ensure that your corrections will be incorporated. If you wish to do this, please follow these instructions:

1. Save the file to your hard disk.

2. Check which version of Adobe Acrobat/Reader you have on your computer. You can do this by clicking on the "Help" tab, and then "About."

If Adobe Reader is not installed, you can get the latest version free from http://get.adobe.com/reader/.

3. If you have Adobe Acrobat/Reader 10 or a later version, click on the "Comment" link at the right-hand side to view the Comments pane.

4. You can then select any text and mark it up for deletion or replacement, or insert new text as needed. Please note that these will clearly be displayed in the Comments pane and secondary annotation is not needed to draw attention to your corrections. If you need to include new sections of text, it is also possible to add a comment to the proofs. To do this, use the Sticky Note tool in the task bar. Please also see our FAQs here: http://journalauthors.tandf.co.uk/production/index.asp.

5. Make sure that you save the file when you close the document before uploading it to CATS using the "Upload File" button on the online correction form. If you have more than one file, please zip them together and then upload the zip file.

If you prefer, you can make your corrections using the CATS online correction form.

\section{Troubleshooting}

Acrobat help: http://helpx.adobe.com/acrobat.html

Reader help: http://helpx.adobe.com/reader.html

Please note that full user guides for earlier versions of these programs are available from the Adobe Help pages by clicking on the link "Previous versions" under the "Help and tutorials" heading from the relevant link above. Commenting functionality is available from Adobe Reader 8.0 onwards and from Adobe Acrobat 7.0 onwards.

Firefox users: Firefox's inbuilt PDF Viewer is set to the default; please see the following for instructions on how to use this and download the PDF to your hard drive: http://support.mozilla.org/en-US/kb/view-pdf-files-firefox-withoutdownloading-them\#w_using-a-pdf-reader-plugin 


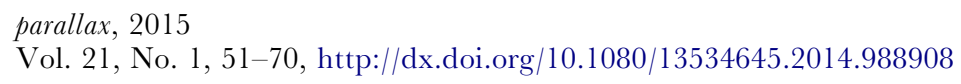

\title{
SÉANCE TENANTE: Deconstruction in (the) Place of Ethics Now
}

\author{
Laurent Milesi
}

\begin{abstract}
There is no ethics without the presence of the other but also, and consequently, without absence, dissimulation, detour, differance, writing. The arche-writing is the origin of morality as of immorality. The nonethical opening of ethics. A violent opening. Jacques Derrida, Of Grammatology, 139-40.
\end{abstract}

One of the perceived hallmarks of 'vintage deconstruction', ever since Derrida's trio of monographs in 1967, has been its questioning of origins and of the plenitude of presence, and more recently - since Specters of Marx grappled with issues of spectrality, messianicity and virtuality - of the contemporary and the 'now'. ${ }^{1}$ Equally prevalent, until Critchley's timely corrective and Bernasconi's earlier work on Derrida's indebtedness to Levinas, ${ }^{2}$ had been the impatience with deconstruction's alleged inability to propose an ethics as well as a politics on grounds that it always defers the critical moment of decision-making, whereas both the so-called ethical choice involving responsibility and political action would be deemed to require for maximum efficiency an urgency of response in the here and now, forthwith, séance tenante. ${ }^{3}$

I would like to revisit such undisputed givens in the light of an alternative, Derridean conception of place, space and temporality, and show how these - which, together with the first-person subject, form the deictics of any act of enunciation and thus would open onto a reflection on performativity and representation (a word which has to be made to resonate in both its aesthetic and political dimensions) - can lead to a more 'absolute', 'archaic' demarcation and reinvention of the 'ethical'.

In Of Hospitality, as a basis for his conception of cosmopolitics and unconditional hospitality, Derrida recalls the Hegelian understanding of 'ethics' (Sittlichkeit) as ethos, as a set of customs characteristic of a place to which it lends its political, national, 'eco-nomic', etc. identity:

the circumscribed field of ethos or ethics, of habitat or time spent as ethos, of Sittlichkeit, of objective morality, especially in the three instances determined by law and Hegel's philosophy of law: the family, bourgeois or civil society, and the State (or the nation-state) [to which one could add the city as polis ${ }^{4}{ }^{4}$ 
Thus, for Derrida, the problem of hospitality, as essential to deconstruction as is justice, ${ }^{5}$ is

coextensive with the ethical problem. It is always about answering for a dwelling place, for one's identity, one's space, one's limits, for the ethos as abode, habitation, house, hearth, family, home. ${ }^{6}$

The ethical implications of the dwelling place (demeure) in relation to the issue of justice-to-come as opposed to law-as-justice will be developed later on, when I argue for what I will call a problematic of the non-lieu in deconstructive ethics. For the moment, and as a preliminary step, I wish to engage with Derrida's spatio-temporal redeployment of the 'now' (maintenant) according to quasi-originary différance, which he famously defined as at once spacing and tempor(al)ization, 'the becoming-time of space and the becoming-space of time' ${ }^{7}$

\section{Main-tenance}

What could be misconstrued as an inventive French rendering of Benjaminian Fetztzeit ('now-time') ${ }^{8}$ is first introduced in 'Signature Event Context', in the discussion of the necessity of a more structural, generalizable absence as a precondition of any act of communication, such as a signature:

By definition, a written signature implies the actual or empirical nonpresence of the signer. But, it will be said, it also marks and retains his having-been-present in a past now, which will remain a future now, and therefore in a now in general, in the transcendental form of nowness (maintenance). This general maintenance is somehow inscribed, stapled to present punctuality, always evident and always singular, in the form of the signature. ${ }^{9}$

Drawing out and reorienting the implications of Husserl's 'retention' and 'protention' already analysed in Speech and Phenomena and 'Différance', ${ }^{10}$ this 'general maintenance' emphasizes the dis-location (spacing) of time at work in the contemporary (temporalizing) - to which Derrida will return in Specters of Marx, substituting to the speculative ontology of presence a spectral hauntology of the messianic and the virtual. Before that, this 'general maintenance' will resurface at the crossroads of aesthetics and ethics, in the intervention on architectural space originally known as 'Point de folie - Maintenant l'architecture'.

In this essay dedicated to the 'follies' of deconstruction-inspired architect Bernard Tschumi in the Parc de la Villette, Derrida attempts to adumbrate a different sociopolitical and ethical conception of habitation, 'the law of the oikos' or another economy (NPM, 90: 'oikonomy') of the habitat. ${ }^{11}$ According to Derrida, Tschumi's architectural follies 'give us to think about what takes place' (NPM, 95), the event in/of a place 'to give a right place to [ fait droit à] dissociation, but to put it to work as such in the space of a gathering' in order to strive towards a spacing and 'a socius of dissociation' (NPM, 100; translation modified). Tschumi's emphasis on dis- (and trans-) processes, 
noted by Derrida, impacts on the relationship between dis-location and communal space; it 'signs a "mad" contract between the socius and dissociation' (NPM, 101) and interrupts a Hegelian dialectic of spatial geometry first explored in the essay 'Ousia and Grammè' (Margins of Philosophy), whereby the 'now' (maintenant) is merely the maintained and suppressed (aufgehoben) truth of the point (NPM, 101) - hence the selfdividing, undialectizable double entendre of point de in 'point de folie', pointing at the 'atopicality' of a madness without madness: ${ }^{12}$

A force joins and holds together the dis-jointed as such. It does not affect the dis- from the outside. The dis-jointed itself, maintaining architecture, the architecture that arrests madness in its dislocation. (NPM 100)

Through a differential process of abstraction, distraction and also subtraction - of architecture from its habitual ends in construction and in 'the value of habitation, 13 Derrida's maintenance points towards an event which breaks with presence, 'maintaining' spacing in dissociation, and the relation to the other as such: 'Non pas la main tenue mais la main tendue par-dessus l'abîme', ${ }^{14}$ i.e. not the hand holding the other here and now - time being the truth of space according to Hegelian dialectic holding him or her to a (socially, politically, economically, etc.) pre-ordained place and position, but the hand held out to the other in dissociation over the abyss that necessarily separates one from the other.

The complicity between deconstruction and a new sense of gathering, association, community, maintaining in maintenant was similarly emphasized in the interview with Peter Brunette and David Wills on spatial arts, soon after Derrida commented on the seeming paradox of putting forward a 'deconstructive architecture' for a 'discipline' whose duty and vocation is traditionally to 'construct':

$[\ldots]$ 'deconstructive architecture' refers precisely to what happens in terms of 'gathering' $[\ldots]$, the being together [être ensemble], the assembly, the now [maintenant], the maintaining. Deconstruction does not consist simply of dissociating or disarticulating or destroying, but of affirming a certain 'being together,' a certain maintenant $[\ldots] .{ }^{15}$

Bearing in mind that droit (law, right) is the necessary preamble to justice(-to-come) in deconstruction ('Force of Law'), to which we will turn in a final movement, the phrase 'faire droit a' which I highlighted above can be made to chime with Derrida's attempt to redefine and understand anew the maintenant:

Maintenant: if the word still designates what happens $[\ldots]$, this imminence of the just (just happens, just happened, is just about to happen) no longer lets itself be inscribed in the ordered sequence of a history $[\ldots]$. (NPM, 88)

Maintenant, therefore, can now be parsed and dissociated, spaced out, as main tenant, tenant par la main, holding hand(s) with (con-) but a company or accompaniment that 
for Derrida, for justice-to-come and a relation to the other-as-such, is always to be envisaged as an $\mathrm{X}$ without $\mathrm{X}$ - such as messianicity without messianism, religion without religion, ${ }^{16}$ society without society, the dissociation of the socius or 'unbinding' (déliaison), ${ }^{17}$ a community without the com-, and therefore open to the auto-immune as a co-immunity ${ }^{18}$ - to which we will eventually add the non-lieu in a last endeavour to formalize the experience of this originary spacing of a place without place. ${ }^{19}$ Tenir, and especially se tenir, a verb also used to indicate ethical deportment, can be heard in this revitalized conception of nowness whereby one should also, as it were, 'speak from / know one's place' when one takes up a stand, stance or position, be constantly aware of the 'ethical' determinations of a time and place of discourse. One may even wish to hear this indirect injunction in the following, seemingly unrelated passage from $H$. C. for Life, That Is to Say..., when Derrida reminisces over Cixous's vision of him walking along a crest, being thus 'placed too high' and deprived of sides, edges and safeguards:

[...] I thus saw myself raised, doomed not to put a foot wrong or step to one side [pas de côté] once, without the slightest safeguard, closer than ever to the fall or the unforgivable mistake. So I would have no side at all, no side for sidestepping [pas de côté pour un pas de côté ]. That's why now I do not know where to put myself [où me tenir]. $[\ldots]$ I'd just better stay put [je n'ai qu'à bien me tenir $].^{20}$

And soon after, ${ }^{21}$ Derrida instructs us to reread Cixous's whole oeuvre, starting with $L a$, for the relationship between those sides 'here' and 'there' $(l a ̈)$ and (se) tenir as well as its prepositional derivations. Cixous, whom he had praised for her generalized 'art of substitution' (remplacement), which had provided the subtitle of her French thèse d'état on James Joyce.

Variations on such teneur and especially tenue are given a more explicitly ethical spin in one of Derrida's seminars on absolute, im-possible hospitality, or 'hostipitality', where a whole derivative kinship, an 'eco-nomy' of language and etymology, is explored:

Being-present as absent for the hôte? Must one be there (living, or surviving, or not)? [...] The hôte always passing through (road and itinerary, iterability: come: come back [viens: reviens]). But must one hold back [re-tenir] the passing hôte? When does holding back and retaining [retenir] him become detaining [détenir] the other as hostage? (to hold, to hold the other, to entertain and support [entre-tenir] the hôte (entertain and sustain $[\ldots])$.

$$
[\ldots]
$$

$[\ldots]$ a seminar on hospitality is a mediation and an exercise of language or of writing about all the possible statements that one can let 'hold' (to hold dear, to maintain, retain, entertain and support, detain [tenir, maintenir, retenir, entretenir, détenir $]$ but also 'letting [laisser $]$ ' $[\ldots] .{ }^{22}$ 
These can be read alongside the recall of what a hostage means and implies, from the short essay also titled 'Hostipitality': 'the hostage is a guarantee for the other, held in a place and taking its place' [tenu dans un lieu et tenant lieu ]. ${ }^{23}$ It is to this place (lieu), in particular in the self-deconstructing phrase au lieu de and what 'takes place' in or with(out) it (tenir lieu de), that I would like to hold on, after going off on a tangent, via Derrida's reflections on a more 'homely' form of the con-: the experience of (con) tact and touching.

\section{Place Holders I - Contingencies and contiguities (noli me ten[d]ere)}

Organized around a haptological framework of four philosophemes (extension, partes extra partes, to touch, to touch oneself) ${ }^{24}$ and offering a piecemeal history of the philosophy of 'tact' in interrelated touches, Derrida's masterly study On Touching Fean-Luc Nancy extends the 'sense of touch' between the cognate families of tenir (Latin tenere) and tendre (tendere - > entendre: to hear, understand [from intendere: to spread, 'tend' towards]). Such is the thematic spread of Derrida's analyses that a recapitulative summary of its main relevant 'points' of articulation is first called for, in quick programmatic shorthand:

- the inaugural 'point' or break of dawn (le jour point) and the discussion of Psyche's corporeal 'extension' (étendue), intact, intangible and untouchable (OT, 3, 17, 16);

- the following 'parenthesis' on 'spacing' or 'the absolute condition of any extension' $(O T, 20)$ and 'the tactile figure of pure auto-affection' in se toucher $(O T$, 32; cf. also p. 34$) ;{ }^{25}$

- the law of tact $^{26}$ as im-possible touch-without-touching (déliaison again, ${ }^{27}$ or the disjunction of contact in the $\left.\operatorname{caress}^{28}\right)$;

- the necessity to 'extend an ear' (entendre) otherwise to the relation between 'to tend(er)' (tendre), intentional, and 'tender' (tendre, i.e. what is soft to the touch / touches the heart), non-intentional $(O T, 94)$, the latter being at the origin of ethics $(O T, 92)$;

- the interruptive touch of the (reflexive or reciprocal) se toucher (interruption in contact, untouchable touchable, etc.; OT, $111 \mathrm{ff}$.), and the relation between prosthetic supplementarity and the spacing-out in contact in Nancy's corpus (OT, 129);

- the five digressive 'Tangents' - 'five, like the five fingers of the hand, like the five senses' $(O T, 182)$ - which in their contingent as well as tangential ${ }^{29}$ 'impertinent pertinence $[\ldots]$ touch $[\ldots]$ only one point' (OT, 131), focusing on the teleological 'exemplarity' of the hand (main) $)^{30}$

- the closing 'Punctuations' (from punctum: point) on a new form of auto-heteroaffection (since there can be no touching / being touched by the other without first touching oneself): 'se toucher-toi' (to self-touch you) - featuring, at one point, 'la tienne', a homophone tactfully tensed between 'yours' and a subjunctive form of tenir $^{31}$ - before a 'Final Retouch' or Salve, '[a] nightless, dayless point' ('[ $p$ ] oint de nuit $[\ldots]$ point de jour'), '[t]o the point, the break of dawn' ('Au point du jour.') ${ }^{32}$

A book also about 'the metonymies of touch' and prosthesis (but also transplants) as 'the metonymic substitute[s]' (OT, 17, 19; also 286), one of its motifs, structuring the 
Milesi

linguistically densest passage of 'Tangent IV', is tenir lieu (de) (to take the place of), a phrase which Derrida had already ascribed to the 'supplement' in his early essay on Rousseau ${ }^{33}$ and which is here redeployed in relation to the spacing of touching as con-tact, as the experience itself of (an ecotechnic and prosthetic) contact. The idiomatic sequence, whose near-untranslatability is noted by Derrida himself, ${ }^{34}$ will be given both in the original and in English, and will be used as a metonymic touchstone for what follows:

A lieu et tient lieu: a lieu tout en tenant lieu, a lieu pour tenir lieu-par le fait de tenir lieu et en vue de tenir lieu: a lieu de tenir lieu: tenant lieu d'avoir lieu. ${ }^{35}$

Taking place and taking the place of: taking place while taking the place of, taking place in lieu of taking the place of - by virtue of taking the place of and in view of taking the place of: held (in place) to taking the place of: taking the place of taking place. (OT, 221)

Among so many reasons and pretexts of friendship which could be adduced to account for Derrida's enduring interest in Nancy's work is no doubt the latter's conception of an 'inoperative community', which tacitly informs his sense of touch and con-tact as both 'participation and partition' but, in retaining the word 'community', is ultimately at odds with Derrida's generalized mistrust of the one and common. ${ }^{36}$ After quoting from Nancy's Being Singular Plural, Derrida further comments on 'the law of parting and sharing at the heart of touching', whose spacing ${ }^{37}$ points to his " inoperative community", another ethics of "the other of the with", (OT, 199; also 200: 'time to space itself', 'dis-tension'), not unlike his own effort to imagine a community without community, or co-immunity (i.e. without the name), which we can now gloss as a tactful touching (one/self-other) otherwise. Derrida's 'interruptive community' (as it could now be called) is 'the interruptive experience of the syncope' $(O T, 162)$, a dissociative ethics of the relation to the other as déliaison (which one could interpret as the abstraction of the bond from the binding) and an irreducibility of the other in the experience of touching $(O T, 223)$ which opposes the more traditional 'community as co-tact' $(O T, 115) .{ }^{38}$

As Hillis Miller rightly pointed out, On Touching is ruled by a general metonymics whereby touch-related words substitute (for) one another in an incessant contiguity which ultimately can only tangentially touch upon touch (as upon Nancy on touching), the untouchability of touch-without-touching, or sole propriety of these improper, 'impertinent' 'concepts' since they all oscillate undecidably between the literal and the figurative. ${ }^{39}$ To recast and extend Mallarmé's famous maxim often invoked by Derrida himself (rien n'aura eu lieu que le lieu): 'nothing takes place but place' while metonymically taking the place of $(O T, 17)$. Such generalizable substitutability - which likewise affects the quasi-synonymic chains of nonce words that traverse Derridean deconstruction - demarcates the fundamentally atopic, secret and elusive, 'dislocated' place of Derrida's writings which cannot 'stay in place' (ne tiennent pas en place, as one would say in French) and instead stage an affirmative place which is 'not a place that really exists', 40 'a place that is not a place, a place-no-place where events take place without taking place'. ${ }^{41}$ 
Derrida's suspensive final 'point' to his last 'Tangent' - after contrasting Chrétien's and Nancy's conceptions of touch, incarnation and corpus as '[t] wo ways of thinking substitution' -suggestively ties together spacing (emplacement), khora, substitution (remplacement) and hospitality in a way that will provide us with a convenient stepping stone if one bears in mind his earlier statement, in The Gift of Death, that ' $[\mathrm{t}]$ he ethical involves me in substitution': ${ }^{42}$

What there would remain to think is the place, the placing of this replacing, or the neutral spacing (chora, I might say), that would still extend its hospitality to this virtual substitution of substitution, unless it should detain [retienne] it forever as a hostage. $(\text { OT, 262 })^{43}$

\section{Place Holders II - In (the) Place of}

In the Seminar on 'Hostipitality', within a context which probes into the significance of using a hostage to political ends while thus resorting to an 'ethics of substitution', Derrida muses on the meaning of substitution, which the classical French dictionary Littré defines as the 'action that consists in putting a thing, a person in the place of [à la place de] another'. Derrida further reflects:

In the place of - locution which names the occupied space, the destined location [emplacement], natural or not, even the lodging, the habitat, the lieu (one also says, for substitution, 'ceci au lieu de cela'), 'at the place of' ['à la place de,' 'au lieu de,' 'en lieu et place de'] [...] $]^{44}$

If, for something called 'communication' to 'take place', it is the pre-condition that any sign (which Derrida prefers to call 'trace', 'gram', 'mark', etc.) ${ }^{45}$ be iterable, graftable and thus be able to operate in absentia rather than merely in the here and now of a unique, original utterance ('Signature Event Context'), this universal singularity comes up against the logic of substitution - or rather the absence thereof in the case of death and witnessing. This issue is taken up in Demeure, a patient, detailed study of Maurice Blanchot's short, enigmatic semi-autobiographical text The Instant of My Death, which contrasts Celan's momentous statement 'Niemand zeugt für den Zeugen' (nobody witnesses for the witness) with a quotation from Blanchot's The Step Not Beyond associating attestation with the Neuter, 'the singular place of a passion beyond the opposition of passive and active ${ }^{46}$ - and let us recall in passing that, within some fifteen years of each other, différance and khôra were equally defined as neither passive nor active. ${ }^{47}$

Demeure also dwells, is built on Derrida's attempt to locate the testimonial, juridical, etc. dimensions of the French idioms mise en demeure, à demeure and suchlike, undecidably caught between the impossibility of deciding and the impossibility of remaining [demeurer] in the undecidable ${ }^{48}$ i.e. the aporia of the critical, ethical moment or 'point of decision (as well as interpretation):

I will attempt to speak of this necessary but impossible abidance [demeurance] of the abode [demeure]. How can one decide what 
remains abidingly [à demeure]? How is one to hear the term - the noun or the verb, the adverbial phrases - 'abode' [la demeure],' 'that which abides [ce qui demeure],' 'that which holds abidingly [ce qui se tient à demeure],' 'that by which one must abide [ce qui met en demeure]'? ${ }^{49}$

Further on, the inessentiality and 'space' of literature - which for Derrida has the right to say any- and everything (le droit de tout dire $)^{50}$ - is affirmed as a lastingly untenable place, a 'passion' as 'the endurance of an indeterminate or undecidable limit', resisting being maintained in a place:

There is no essence or substance of literature: literature is not. It does not exist. It does not remain at home, abidingly [à demeure] in the identity of a nature or even of a historical being identical with itself. It does not maintain itself abidingly [à demeure], at least if 'abode [demeure]' designates the essential stability of a place; it only remains [demeure ] where and if 'to be abidingly [être à demeure]' in some 'abiding order [mise en demeure]' means something else. ${ }^{51}$

One reason why literature is so special and should be upheld - including against those that would want to legislate over its contents (and here one should not forget Derrida's instrumental role in setting up the International Parliament of Writers at the time of the fatwa against Rushdie) - is that its irreducibly undecidable status, between fiction and testimony, even for instance when a text claims to be a truthful autobiography, its defiance of a stable, stabilized, 'maintained' resting place, confers upon it the privilege of being the utmost test for, and experience of, the suspension of judgment. In the 1987 intervention at the Collège International de Philosophie forum on 'Ethics and Politics' alluded to in the beginning, Derrida had already outlined in not dissimilar terms the possibility of a new place or space beyond ethics as it is usually constrained to a decisional space in our society, a non-space of the form $\mathrm{X}$ without $\mathrm{X}$ to which he will return time and again in the 1990s:

What you have just evoked is a zone of experience; it is on the basis of nondecision, not of indecision but of nondecision, that the decision emerges. I would completely agree with you in making me attentive to this experience that is not commanded by a decision. I would simply have some reservation when you call this space a political or ethical space. I think that, in our tradition and in our society, when we think of ethics and politics, a decision is irreducible. The moment of the decision one cannot do without it. And this community, this dimension of being together that would not be ruled by the necessity of decision, I am very attentive to it, indeed, but I will not define it as ethical or political. There are, perhaps, dimensions of the community, of being together - the word community has always bothered me a little - of being together in the interruption, as one says today, in a relation without relation, which are, perhaps, neither ethical nor political. But when there are ethics and politics - at that moment, one 
must decide. [...] And what one calls ethics or politics in our culture, is the moment at which one cannot not decide. There are decisions to be made, which are inevitable, and not decide is still to decide. The space of the decision here is irreducible. This does not prevent us from thinking of something that is before or after or further... This does not prevent us from being-in-the-other or from opening, from knowing that a space is open with the other in which this decisionism does not take place. Nevertheless, there are places where it takes place. And this taking place is what one calls, I think, the ethical and the political in our society. ${ }^{52}$

Taking place, here and now: this is what politics and ethics are also (said to be) eventually about, as Derrida recalls in 'Force of Law' in relation to the instant of madness of the just decision, whose urgency and precipitation necessarily interrupts the juridico-ethico-political status quo and order. ${ }^{53} \operatorname{Propr}(\mathrm{i})$ ety or the appropriateness of place is also at issue in the second part of Khôra when it alludes to the Socratic discourse, featured towards the opening of Plato's Timaeus, which distinguishes between philosophers and politicians, both having a proper place ('ont lieu'), ${ }^{54}$ versus the poets and sophists who migrate from place to place, and the non-place which Socrates feigns to occupy in his address, 'in the neutral space or a place without place'. ${ }^{55}$ Hence Derrida's comment in Archive Fever that the virtual 'takes place' otherwise and by necessity makes us renegotiate 'the full and effective actuality of the taking-place, the reality [...] of the archived event', ${ }^{56}$ and more crucially, towards the end of Specters of Marx, his call to rethink what we still unquestionably place under 'politics', and the age-old, implicit conception of the political space of 'representation' still bound with presence in spite of all the emergent teletechnologies. ${ }^{57}$ It is from this usual place for politics and ethics that deconstruction aims to demarcate a non-place that will reveal those constitutive differences in placements and bring to light the 'ante-primal' (avant-premier) ${ }^{58}$ idiom for absolute responsibility, not the question of (the 'present' of) being and essence (es gibt Sein) but the issue of place: il y a lieu (de), as one says in French about the injunction of a dictating necessity. A pre-critical, pre-ethical non-space upon which the possibility of any ethos is therefore conditional, which I would now like to summon by another untranslatable term, borrowed from legal discourse: non-lieu (lit.: non-place), used when a plaintiff is debarred from a case and a verdict is returned by not being returned, when conditions for the exercise of justice are not met.

\section{'Non-lieu', or, How to be just in (the) place of ethics ${ }^{59}$ \\ [...] justly mad; just to be mad; just like a certain kind of madness $(O T, 56)$}

Originally collected in the 1987 Poikilia for Jean-Pierre Vernant, the essay on the Platonic khora elaborates the difficult reading/translation of the non-place of such a 'place', which gives rise to - donne lieu - without giving anything like an essential place or foundation, ${ }^{60}$ a spacing (différance) in a withdrawal of 'the place' from 'place', place without place. As opposed to the presence-as-reference/referent of a negativized essence in the via negativa or negative theology, khôra is neither a 
reference nor a referent, a '(non-)place' which 'takes place' [a lieu] without a place instead - au lieu de: 'There is khôra but the khôra does not exist. ${ }^{61}$ Or in Mallarmé's celebrated poetic formula again, rien n'aura eu lieu que le lieu; but a taking place as the pre-originary spacing of pre-critical différance.

One of the significant additions to the 1993 republication in book form of the essay on khora is the framing opening echo of the arrivant, which, in the context of contemporaneous writings like Aporias and Specters of Marx, testifies to the discreet recentring on issues of ethics, responsibility and the messianic, of Derrida's meditations on a more originary, unanticipatable, ante-primal 'place'. His opening in the original, 'Khôra nous arrive..., ${ }^{62}$ allows us to reread this necessary prior-tothe-first place or pre-originary (non-) place as absolute giving as well as pre-given, though not of an essential kind, which conditions subsequent determinations of places and from which questions of ethics, hospitality or responsibility towards the Other, etc. ought to be asked for their radical legitimacy. An aporetic topography combined with a necessity to apprehend 'an abyss in these places', to which Derrida will return in 'Faith and Knowledge', ${ }^{63}$ with the abstract 'figuration' of the desert within the desert, that ante-primal withdrawal of place from place or 'retreat' [retraite], an aporetic space that gives place to, and thus enables the various discourses on, ethics to take place - a double aporia since the retreat within also means withdrawal, without, as in the unbinding within the communal, the relation without relation in society, or re-ligion without re-ligion. ${ }^{64}$ Thus, for Derrida, the religious without religion would be the originary lien sans lien (déliaison) that would make possible the gathering together without / before community or sociality ('the social nexus') that erases subjectivities in the name of a promised collectivity and revealed universality, the free inhabiting together of / Mitsein in a place. If 'Before the Law' il y a lieu (one must, it is necessary), ${ }^{65}$ such anteriority, before the necessary foundation of lawas-justice posited in 'Force of Law', can only take place as the risk of critical suspensiveness in the non-lieu of justice-to-come. ${ }^{66}$

I began by alluding to the timely re-reading of Derrida, which, from the late 1980s onwards, set out to ethicize deconstruction, usually with a Levinasian agenda. A recent challenge to this historically necessary corrective came from Martin Hägglund's razor-sharp Radical Atheism: Derrida and the Time of Life, which mined the hitherto untapped significance of Derrida's mention of a violent 'nonethical opening of ethics' in Of Grammatology ${ }^{67}$ in conjunction with the becoming-space of time and becoming-time of space in différance to mount a cogent claim for deconstruction's assertion of an inaugural arche-violence and radical evil in the opening of life. Kicking off with an outline of the 'ultratranscendental' trace-structure of time and 'succession' in general in order to argue for the autoimmunity of life and emphasize that human desire for immortality is in fact a desire for survival, Radical Atheism then takes head-on in three successive chapters three reductive readings of Derridean deconstruction in terms of ethics (Critchley, Bernasconi, Drucilla Cornell), ${ }^{68}$ religion (Caputo) and politics (Laclau, via Freudian-Lacanian psychoanalysis). Hägglund's strategy throughout is to highlight a common lack of 'radicality', stemming from critics' failure to gauge the importance of the trace-structure and autoimmunity, around correlated sets of themes that include the unconditionality of hospitality in relation to an ethics of alterity, the religious ideal of absolute 
immunity, and the desire for plenitude in political commitment to 'justice' and 'democracy'. These sites of contention subsequently gave rise to several debates and polemics, among which those with Laclau (on the role of the desire and 'drive for survival' versus Laclau's hegemonic 'drive for fullness' in radical politics), Attridge (on the ethical relation between conditional and unconditional hospitality, calculability and incalculability) and Caputo (on the uncontaminated priority of the good, equated with 'God', in his 'weak theology' versus autoimmunity, radical evil (both from 'Faith and Knowledge') and Hägglund's logic of radical atheism displacing a former debate on the relation between deconstruction and negative theology - are perhaps the most notorious as they bear more crucially on the core of Hägglund's trenchant project. ${ }^{69}$ While in some respects these various controversies and interventions are intricately enmeshed, I will avail myself of Hägglund's Nietzschean penchant 'to philosophize with the hammer ${ }^{70}$ and forcefully extract those ethics-related strands in his replies and responses that more specifically dovetail with the arguments and scope of this essay.

A central charge against Hägglund is his failure to operate a more interruptive 'contaminating logics' typical of deconstruction, rather than performing dialectical reversals (Laclau), as well as the 'one-sidedness' of his conception of hospitality as a prime instance of the relationship to the other, which voids any ethics of unconditional hospitality of the power to decide in front of the event (Attridge) ${ }^{71}$ Indeed, for Hägglund, it is not 'unconditional hospitality to otherness' which is ethical, since unconditionality is a necessary condition of the event's unpredictability and ' $[u]$ nconditional hospitality is thus another name for the exposure to temporal alterity', ${ }^{72}$ but the resulting need to calculate with incalculable circumstances in order to be able to make justifiable decisions. Hence, the following clear-cut position, backed up by key passages from Derrida's more recent texts as evidence which are worth quoting more fully:

The ethical is therefore a matter of responding to alterity by making decisions and calculations, whereas the unconditional is the nonethical opening of ethics, namely, the exposure to an undecidable other that makes it necessary to decide and calculate in the first place. $^{73}$

I have always, consistently and insistently, held unconditional hospitality, as impossible, to be heterogeneous to the political, the juridical, and even the ethical. But the impossible is not nothing. It is even that which happens, which comes, by definition. [...] There are, it is true, paradoxical or aporetic relations between two concepts that are at once heterogeneous and inseparable, unconditional hospitality and conditional hospitality (that is, the only one, let me repeat it, that belongs to the order of laws, rules, and norms - whether ethical, juridical, or political $[\ldots] .^{74}$

Political, juridical, and ethical responsibilities have their place, if they take place, only in this transaction - which is each time unique, like an 
event - between these two hospitalities, the unconditional and the conditional. $^{75}$

Therefore, for Hägglund, '[w]hat Derrida describes under the heading of unconditional hospitality is $[\ldots]$ the non-ethical opening of ethics' and ' $[t]$ he task of deconstructive analysis is not to choose between calculation and the incalculable, but to articulate their co-implication and the autoimmunity that follows from it. ${ }^{76}$

Co-implication (of the conditional and unconditional, calculable and incalculable, but also of evil in good, death in life, etc.) is a crucial argumentative fulcrum here and elsewhere, and one should not forget that it already operates in the reversible formulation of différance linking spacing and temporality. Its logic also haunts another recurrent facet in these polemics: the strangely enduring 'critical' opposition between the internal and the external which Hägglund's interlocutors often insist on maintaining, in spite of Derrida's near-constant problematization of margins, limits and borders, parergonal effects of inscription, or specific texts like 'The Outside Is the Inside' (Of Grammatology) and 'Fors', on the untenability of a topical distinction between introjection and incorporation, an inner or outer forum of the self (for intérieur or public forum), etc. Hence, for Hägglund (to redirect Laclau's own critique), Caputo's pious argument about the priority of the good is still entrenched in a set of binary, deconstructible oppositions - between the originary, internal promise (good) and the externally derived threat (evil) - and fails to grasp the structural necessity and logical co-implication that always already operates and autoimmunely contaminates or 'haunts' from within. ${ }^{77}$ Restaged in terms of différance, the unconditional is 'the co-implication of time and space that [Derrida] calls spacing. ${ }^{, 78}$

The insistence on the structural inscription ${ }^{79}$ of radical autoimmunity - to recall that the Derridean formula developed by Hägglund, 'the nonethical opening of ethics', was first ventured in conjunction with archi-écriture, and since Caputo objects to Hägglund's choice of 'descriptive' (vs. prescriptive) - is reminiscent of the even fiercer debate that had pitted Derrida and Lacan (and their respective followers) against each other about the joint issues - and the necessary correlation in Lacan's interpretive system of the Seminar - of the non-partitivity of the letter and its surefire arrival at its destination in Poe's tale of 'The Purloined Letter', a Lacanian 'desire for plenitude' countered by Derrida's structural 'law' of dissemination and destinerrance:

The divisibility of the letter $[\ldots]$ is what chances and sets off course, without guarantee of return, the remaining [restance] of anything whatsoever: a letter does not always arrive at its destination, and from the moment that this possibility belongs to its structure one can say that it never truly arrives, that when it does arrive its capacity not to arrive torments it with an internal drifting. ${ }^{80}$

Thus, and comparably, Hägglund is right to insist on what I will rephrase as the selfdivisibility of/within autoimmunity (as in Derrida's use of the double-edged sauf par: 
save by in 'Faith and Knowledge' to counter religion's desire for the unscathed ${ }^{81}$ ), for which Caputo refuses to make allowances in his apprehension of deconstruction as 'ankhôral religion without religion'. To use another 'privative' formula, I would venture that the over-zealous ethicization of Derrida has also resulted in a paradoxical 'ethics without ethics', which subtracts the dimension of spacing and of the dis-location of place (ethos) from deconstruction and ultimately dismisses the autoimmunitary dimension of the nonethical opening of ethics. A non-lieu has been dispensed unjustly in place of the differential (non-) lieu of deconstruction...

Whereas many of the polemics that ensued from Hägglund's Radical Atheism dealt, in one way or another, with the temporal dimension and anchoring of his project ('taking [the] time [to live]'), the aim of this essay, and its arc from the spacing of main-tenance to the non-lieu, was also to 'relocate' Derrida's alleged 'ethical turn ${ }^{, 82}$ squarely within the broader context of his long-standing thinking of place and 'taking place', which is indissociable from some of the major structural operators of deconstruction, such as différance. More specifically, its belated contribution to the recent debates surrounding deconstruction and ethics lies in its attempt to articulate the '(non-)place' of the ethical in Derrida as a reformulation of the violent spacing ('becoming-space of time') at work in 'the nonethical opening of ethics'. ${ }^{83}$

Such in my view is Derrida's call for a more archaic, 'ethical' place (without place), out of place and out of time - his maintenance or, in Specters of Marx, 'the disadjustment of the con-temporary ${ }^{84}$ - the desert within the desert of what the French double syntax calls 'le risque en demeure indéniable ${ }^{\text {}} 85$ rather than a mise en demeure, abstracted, sub-tracted through an abyssal hollowing out of the desert, of what 'place' and 'in (the) place of' (au lieu de) mean, and which famously prompted Emmanuel Levinas to observe, in 'Jacques Derrida: Wholly Otherwise', that Philosophy's panorama, before and after Derrida, shifts from 'everything is in place' to 'nothing is left inhabitable for thought', 'everything is [...] left desolate'. ${ }^{86}$

\section{Notes}

${ }^{1}$ Derrida, Specters of Marx, xiii. About the 'noncontemporaneity with itself of the living present' see also 24-25, 39, 73, 75 .

${ }^{2}$ See Critchley, The Ethics of Deconstruction and the two items under 'Bernasconi' in the Bibliography. In his more recent Ethics-Politics-Subjectivity, Critchley still traces the ethical potential of Derrida's work to Levinasian ethical experience.

${ }^{3}$ Derrida addresses this point for e.g. in $\mathcal{N}$ egotiations, 302 ('Ethics and Politics Today').

${ }^{4}$ Derrida, Of Hospitality, 45 (see also 23). The equation between ethos and habitus is also mentioned in the title essay of Negotiations, 13, and accounts for this same word 'habitat' being used to describe the global place of Derrida's infinite ethics in The Gift of Death, 69.

${ }^{5}$ See Derrida, Acts of Religion, 364 ('Hostipitality'): 'Hospitality is the deconstruction of the at- home; deconstruction is hospitality to the other $[\ldots]$ ', and the famous axiomatic equation 'Deconstruction is justice' in 'Force of Law,' 243.

${ }^{6}$ Derrida, Of Hospitality, 149, 151. In The Ethics of Deconstruction, Critchley recalls the more specifically Heideggerian determination of ethos as abode or dwelling place (15).

7 Derrida, Margins of Philosophy, 8-10, 15 ('Différance,' 8). The importance of this reversible formula, related to the trace as (palindromically) écart (gap), was repeated years later in connection with democracy in Rogues, 38. '[I] rreducible spacing (the first word of any deconstruction, valid for space as well as time)' is also emphasized in $O n$ Touching, 181, to which we shall return. It is worth recalling that maintenant is derived from Latin manu tenendo (the gerund of manu tenere: to maintain): while holding in the hand, hence rapidity of 
gesture, then temporal promptitude or extreme local proximity, and temporal proximity (Le Trésor de la Langue Française informatisé online, at http:// atilf.atilf.fr/tlf.html, s. v. 'maintenant').

${ }^{8}$ This cautionary remark is also a pretext for signalling one of the distant touchstones of this essay: understanding how in Derridean thought the insistent motif of the avenir / à venir or time to come, which is reduced to an eternal deferment of politics by its detractors - justice-to-come, democracy-to-come, but also a more aprioric, disjunctive messianicity without messianism to which we will soon allude - is not to be too hastily assimilated into a theological (Jewish) tradition, of the kind which has been recently traced out in Levine, A Weak Messianic Power, nor even with Walter Benjamin's historico-materialist notion of 'weak messianic power', in spite of some degree of consonance; see Derrida, Specters of Marx, 181, n. 2 (also 21, 55), and 'Marx \& Sons,' 250-1. For arguments in this sense, see also Ware, 'Dialectic of the Past' - who notes that 'For Benjamin, messianic time is a way of viewing the past ethically. Disjointed time, on the other hand, allows Derrida to view the future-to-come as the site of justice.' (107) - and Khatib, 'Derrida \& Sons'.

${ }^{9}$ Derrida, Margins of Philosophy, 328.

${ }^{10}$ Derrida, Speech and Phenomena, especially in 'Différance': 'The use of language or the employment of any code which implies a play of forms $[\ldots]$ also presupposes a retention and protention of differences, a spacing and temporalizing, a play of traces.' (146)

${ }^{11}$ Derrida, 'No (Point of) Madness,' especially 90, 91. Hereafter NPM with page references in the text. For a chronology of Derrida's ten-year-long engagement with architecture (1984-1993) and an examination of the relation between the present and the politics of space and place ('ontopology'; Derrida, Specters of Marx, 82), see Vitale, 'Jacques Derrida and the Politics of Architecture', as well as 'The Law of the Oikos', which refers to Derrida's unpublished 1985-86 seminar 'Nationalité et nationalisme philosophique; mythos, logos, topos' in his discussion of khora.

${ }^{12}$ Let us also recall, after Derrida, that atopos: without place, also meant 'mad' or 'extravagant' in Greek. See Derrida, 'How to Avoid Speaking,' 163, and Geneses, Genealogies, Genres, and Geniuses, 59. Derrida has often quoted or alluded to Kierkegaard's famous, if elusive maxim 'the instant of decision is madness' ever since it featured as the first epigraph to his 1963 lecture on Foucault, 'Cogito and the History of Madness' - see Bennington, 'A Moment of Madness' - which can be regarded as a 'watchword' for deconstruc- tion as invention and its frequent self-determination as 'the experience of the impossible'. See for e.g. the interview 'A "Madness" Must Watch over Thinking,' in Points..., 363, and On Touching, 57, which associates the madness of thinking the event with 'the impossible is what takes place'.

13 See Derrida's essay 'Fifty-two Aphorisms,' in Papadakis, Deconstruction Omnibus Volume, 68 (no. 29), and also 72, in the following discussion with Chris Norris.

14 Derrida, Psyche. Inventions de l'autre, 492. Cf. NPM, 102

${ }^{15}$ Derrida, in Brunette and Wills, 'The Spatial Arts,' 27.

16 What John Caputo, combining it with khora as place without (the) place, called 'ankhôral religion without religion'; see Caputo, The Prayers and Tears of Jacques Derrida, 189.

17 For this 'interruptive unravelling' (déliaison) as the condition of the social bond of a 'community', of a bond (socius or desmos) without bond, see for example Derrida, 'Faith and Knowledge,' especially 64.

18 Derrida, 'Faith and Knowledge,' 51.

19 Derrida recalls that it is within a certain experience of spacing and space that resistance to philosophical authority can be produced. See Brunette and Wills, 'The Spatial Arts,' 19, and also Derrida's contemporaneous essay 'Fifty-two Aphorisms,' in Papadakis, Deconstruction Omnibus Volume, especially 68 (no. 26), about 'to make space', which states that the 'aphorism', succinctly described as 'un point c'est tout' (68, no. 25), has 'no inhabitable place', '[n]o housing' (68-69, nos. 40, 41), and concludes: 'To maintain [...], despite all the reappropriations, the chance of the aphorism, is to keep [...] the promise of making room for [donner lieu $][\ldots]$ ' $(69$, no. 52).

${ }^{20}$ Derrida, H. C. for Life, 49. This episode was first evoked in a 1992 talk by Cixous herself on the occasion of the ten-day conference 'Le passage des frontières'; see Cixous, 'What is it o'clock?,' 48

${ }^{21}$ Derrida, H. C. for Life, 50-51.

${ }^{22}$ Derrida, Acts of Religion, 408-09 ('Hostipitality').

${ }^{23}$ Derrida, 'Hostipitality,' 9.

${ }^{24}$ Derrida, On Touching, 16; hereafter OT with page references in the text.

25 Commenting on Nancy's The Experience of Freedom, this second chapter of the first part associates spacing, decision and ethos $(O T, 21-$ 22 ), considering the mouth as the opening that spaces itself out, at once place and non-place of a dis-location $(O T, 28-29)$.

${ }^{26}$ Formulated in French, as on the 'model' of cendre and khôra: 'il y a là loi du tact'; see Derrida, Le toucher, 82. 
27 Derrida, Le toucher, 86.

28 'toucher sans toucher $[\ldots]$, donner sans retenir, mais avec retenue, donner à tenir sans tenir [...]: tiens!' (Derrida, Le toucher, 91); cf. On Touching, 76. There is no space here to do justice to the untranslatable versatility of the French imperative tiens!

29 Derrida, Le toucher, 151 - cf. OT, 131, which strangely omits the first adjective; these also form part of the chain of subtitles for Tangents IV and V.

${ }^{30}$ Just as touch has often featured in philosophical tradition as the essential metonymy of the 'community' of senses par excellence (OT, passim). See also Derrida, 'Heidegger's Hand,' and chapter 11 of Hillis Miller's For Derrida ('Touching Derrida Touching Nancy'), especially $285 \mathrm{ff}$.

31 And elided in the translation; compare Le toucher 314, and $O T, 278$.

${ }^{32}$ See Derrida, Le toucher, 343, and OT, 307.

${ }^{33}$ Derrida, Of Grammatology, 145 ('That Dangerous Supplement...').

${ }^{34}$ Derrida has often evoked deconstruction as an (other) experience of the (im-possible) translation, here subsequently defined as an event which ' $a$ lieu de tenir lieu' (Le toucher, 251); cf. OT, 221.

${ }^{35}$ Derrida, Le toucher, 249.

${ }^{36}$ See Derrida, A Taste for the Secret, 25.

37 Spacing ('spacing space'), and the sharing of being and singularities as spacing, is also evoked in the discussion of Nancy's The Experience of Freedom in Rogues, 46, 50.

${ }^{38}$ See also Rogues, 153, which discusses 'the incalculable event', 'the irreducible spacing of the very faith, credit, or belief without which there would be no social bond [...]'.

39 Miller, For Derrida, 270, 273.

40 Derrida, in Brunette and Wills, 'The Spatial Arts,' 26, who then relates it to Blanchot's 'come [viens]'.

41 Miller, 'Derrida's Topographies,' 307; also 196-7. Cf. Anne Berger's shrewd formulation to Derrida in the interview "Dialanguages"': 'It would be as if, in a certain way, you knew the place that would allow you to write it [i.e. the book to be written], as if you had found it, and at the same time it were lost to you.' (Points..., 149).

${ }^{42}$ See Derrida, The Gift of Death, 61. The sacrificial violence at the heart of this substitutability is performatively at work in Derrida's deceptively non-tautological catchword 'tout autre est tout autre' (68 and chap. 4, 82 ff.) and in the subsequent passage: 'As soon as I enter into a relation with the other $[\ldots]$, I know that I can respond only by sacrificing ethics, that is, by sacrificing whatever obliges me to also respond, in the same way, in the same instant, to all the others.'
${ }^{43}$ For another conjunction of khora and spacing, see Rogues, 82, but also xiv as 'another "takingplace," the irreplaceable place or placement of a "desert in the desert".

${ }^{44}$ Derrida, Acts of Religion, 416 ('Hostipitality').

45 For a succinct development of this substitution, see Milesi, 'Semiology and Deconstruction'.

${ }^{46}$ Derrida, Demeure, 31.

47 Derrida, Margins of Philosophy, 9 ('Différance'); 'How to Avoid Speaking,' 173. For a correlation between 'differential space', conceived as between 'temporal-messianic' and geometrical (ideal), and khora ('Derrida's attempt to recast différance in $[\ldots]$ its $[\ldots]$ spatial [aspect]'), see for e.g. Srajek, In the Margins of Deconstruction, 241 (245), and the whole section on 'Khora' (241-46).

${ }^{48}$ Compare with Derrida, The Beast and the Sovereign, 173: 'The point is that it is a matter of indecision or an indeterminacy between a determinacy and an indeterminacy.'

49 Derrida, Demeure, 16.

50 See Derrida, “"This Strange Institution Called Literature,", 36.

51 Derrida, Demeure, 28.

52 Derrida, Negotiations, 311-12 ('Ethics and Politics').

53 Derrida, 'Force of Law,' 255.

54 See Derrida, Khôra, 55 - in English: 'Khora,' 107.

55 Derrida, 'Khôra,' 109. In Architectural Philosophy, Andrew Benjamin poses as a 'legitimate' consequence of the 'foundational' question about the place that generates all places - the 'logic of khora' - the question of the 'place of the question of place', as the question which 'cannot be included within that which it is taken to found', 'the problem of the foundation of both law and ethos' (13 ff. [15, 14]) analogous to the 'forceful' foundation of law-as-justice in 'Force of Law'.

The lieu sans lieu can be traced back to Blanchot's use of the formula in The Infinite Conversation, 385 ('The Absence of the Book', about the neutral), and Friendship, 116 (see also 47). As if to tacitly point to a common leitmotif, it was finally reprised towards the end of a 1990 homage to the French philosopher; see Blanchot, 'Thanks (Be Given) to Jacques Derrida,' 323 ('(atopical) place without place').

${ }^{56}$ Derrida, Archive Fever, 66.

57 Derrida, Specters of Marx, especially 163, 169.

${ }^{58}$ For this notion, see Derrida, Monolingualism of the Other, 64 ('prior-to-the-first'), 67-69, 71; and 'Faith and Knowledge,' 21, about the 'chora' or 'desert in the desert' - for which see also Milesi, 'Thinking (Through) the Desert'.

59 In what follows, the more ironic, self-deconstructing ambiguity of 'just' should also be borne in 
mind, as in the self-assumed ' $j$ e suis juste en tant que fuif: I am just (about) as a Jew, however missed out in the translation of 'Abraham, the Other,' 11. See also Milesi, 'Portrait of H. C. as J. D. and Back,' 76, and 78-79 in connection with the intersecting motif, first uttered in 'Circumfession", of 'le dernier des Fuifs' (the 1(e)ast of the Jews).

60 For the deconstruction of this term, see Derrida, 'Force of Law,' 230-98, and 'Faith and Knowledge,' 19 (about the 'desert' as found(er)ing).

61 Derrida, 'Khora,' 97. The 'epochality' of such [a] place is an event; see Derrida, 'How to Avoid Speaking,' 173.

${ }^{62}$ Derrida, Khôra, 15; imprecisely translated as, simply, 'reaches us' in the English version ('Khora,' 89).

63 Derrida, 'Faith and Knowledge,' 7.

64 For Derrida's recall of the double Latin filiation of gathering (relegere) and binding (religare) in 'religion', see 'Faith and Knowledge,' 54.

65 See Derrida, 'Before the Law,' 210 (also 215), and Cinders, 37 (also 15, 39).

66 I have developed the implications of this Mallarméan line in relation to Khôra but also Cinders (Feu la cendre) in 'Thinking (Through) the Desert', especially 75.

67 Of Grammatology, 140; first quoted in Hägglund, Radical Atheism, 75, then developed on pp. 88-89, 97, 99, 102, 105, 222 n. 25.

68 In an earlier study of deconstruction's trajectory from phenomenology to ethics, Christina Howells had already signalled that 'Critchley makes a strong case, perhaps too strong a case, for the Levinasian quality of Derrida's ethics.' (Derrida, 124).

69 A full, non-chronological listing of these critical debates and their respective publications erroneously giving 'The Impossibility of Ethics' instead of 'Radical Atheism and Unconditional Responsibility' as the chapter republication, in Reading and Responsibility: Deconstruction Traces, of Attridge's review of Radical Atheism - can be found on Martin Hägglund's site at http://www. martinhagglund.se/. See in particular Laclau, 'Is Radical Atheism a Good Name for Deconstruction?' and Hägglund, 'Time, Desire, Politics' (2008); the special issue of The New Centennial Review, with Hägglund's response, 'The Challenge of Radical Atheism' (Spring 2009); Attridge's Review of Radical Atheism and Hägglund, 'The Non-Ethical Opening of Ethics' (2009-2010); Caputo, 'The Return of Anti-Religion' and Hägglund, 'The Radical Evil of Deconstruction' (2011).

70 Hägglund, Radical Atheism, ix.

71 Laclau, 'Is Radical Atheism a Good Name for Deconstruction?,' 181; Attridge, 'Radical Atheism and Unconditional Responsibility,'14e, 144, quoting from Radical Atheism, 103.

72 Hägglund, 'The Non-Ethical Opening of Ethics,' 299, and also 300, which describes the relation between conditionality and unconditionality as autoimmune.

73 Hägglund, 'The Non-Ethical Opening of Ethics,' 301, and 304-5, n. 5.

74 Derrida, Rogues, 172-73, n. 12; see also 150 about 'the autoimmune aporia of this impossible transaction between the conditional and the unconditional, calculation and the incalculable.'

75 Derrida, 'Autoimmunity: Real and Symbolic Suicides,' 130.

76 Hägglund, 'The Non-Ethical Opening of Ethics,' 302 (almost repeated verbatim in 'The Radical Evil of Deconstruction,'143). See also his conclusion on how to reinvent ethics in the name of deconstruction, 303.

77 Hägglund, 'The Radical Evil of Deconstruction,' e.g. 130, n. 13, and 131 .

78 Hägglund, 'The Challenge of Radical Atheism,' 237.

79 The necessity of inscription, which follows from the structure of succession, is also discussed in relation to the trace-as-erasure of the now by Hägglund in 'The Challenge of Radical Atheism,' 239, soon after stating that Derrida used writing 'to explain the transcendental nature of spacing'.

80 Derrida, The Post Card, 489 ('Le facteur de la vérité'); bold emphasis mine.

81 Derrida, 'Faith and Knowledge,' 25.

82 See Rogues, 39, for Derrida's denying the advent of a political or ethical turn in deconstruction in the 1980 s or $1990 \mathrm{~s}$.

83 I have engaged more specifically with the relation between pre-ethical violence and ethical nonviolence, the notion of 'force', and the performativity of deconstructive syntax in a companion study titled 'Breaching Ethics: Performing Deconstruction', first given as a plenary lecture at the International Conference on 'Ethos Pathos Logos' (University of Ploieşti, October 2012) and, in a revised iteration (in French), as a keynote for the Fifth International Colloquium Writing: Language and Thought on 'Each time, the impossible (Derrida (ten years later)' (University of Brasilia, 29 September-3 October 2014). The present article can therefore be regarded as the first half of a critical diptych on my understanding of 'ethics' in deconstruction.

84 Derrida, Specters of Marx, 99; hyphens and italics mine.

85 Derrida, 'Foi et savoir,' 27; cf. the reductive, monosemic translation in 'Faith and Knowledge,' 17.

86 Levinas, Proper Names, 56

Milesi 


\section{Bibliography}

Attridge, Derek. "Reading and Responsibility: Deconstruction's Traces." Chap. 10 in Reading and Responsibility: Deconstruction's Traces. Edinburgh: Edinburgh University Press, Originally published in Derrida Today 2, no. 2 (2009): 271-81 2010.

Benjamin, Andrew. Architectural Philosophy. London: Athlone, 2000.

Bennington, Geoffrey. "A Moment of Madness: Derrida's Kierkegaard." The Oxford Literary Review 33, no. 1 (2011): 103-127.

Bernasconi, Robert. "Deconstruction and the Possibility of Ethics." In Deconstruction and Philosophy: The Texts of Jacques Derrida, edited by John Sallis, 122-139. Chicago: University of Chicago Press, 1987.

Bernasconi, Robert. "The Trace of Levinas in Derrida." In Derrida and 'Différance, edited by David Wood and Robert Bernasconi, 13-29. Evanston: Northwestern University Press, 1988.

Blanchot, Maurice. Friendship. Translated by Elizabeth Rottenberg. Stanford: Stanford University Press, 1997.

Blanchot, Maurice. The Infinite Conversation. Translated and foreword by Susan Hanson. Minneapolis: University of Minnesota Press, 1993.

Blanchot, Maurice. "Thanks (Be Given) to Jacques Derrida." Translated by Leslie Hill In The Blanchot Reader, edited by Michael Holland, 317-323. Oxford: Blackwell, 1995.

Brunette, Peter, and David Wills. "The Spatial Arts: An Interview with Jacques Derrida." Translated by Laurie Volpe In Deconstruction and the Visual Arts: Art, Media, Architecture, edited by Peter Brunette and David Wills, 9-32. Cambridge: Cambridge University Press, 1994.

Caputo, John D. The Prayers and Tears of Facques Derrida: Religion without Religion. Bloomington and Indianapolis: Indiana University Press, 1997.

Caputo, John D. "The Return of Anti-Religion: From Radical Atheism to Radical Theology." fournal for Cultural and Religious Theory 11, no. 2 (2011): 32-124.

Cixous, Hélène. "What is it o'clock? or The door (we never enter)." Translated by Catherine A.F. MacGillivray Stigmata: Escaping Texts, with a foreword by Jacques Derrida and a new preface by the author, 57-83. London: Routledge, 2005 [1998].

Critchley, Simon. Ethics-Politics-Subjectivity: Derrida, Levinas and Contemporary French Thought. London: Verso, 2009.

Critchley, Simon. The Ethics of Deconstruction: Derrida and Levinas. 2nd edn. Edinburgh: Edinburgh University Press, 1999.

Derrida, Jacques. "Abraham, the Other." In Fudeities: Questions for Facques Derrida. trans. Bettina Bergo and Michael B. Smith, edited by Bettina Bergo, Joseph Cohen, and Raphael Zagury-Orly, 1-35. New York: Fordham UP, 2007.

Derrida, Jacques. Acts of Religion. Edited and with an introduction by Gil Anidjar. New York: Routledge, 2002.

Derrida, Jacques. Archive Fever: A Freudian Impression. Translated by Eric Prenowitz. Chicago: University of Chicago Press, 1996.

Derrida, Jacques. "Autoimmunity: Real and Symbolic Suicides. A Dialogue with Jacques Derrida." Translated by Pascale-Anne Brault and Michael Naas In Philosophy in a Time of Terror: Dialogues with Fürgen Habermas and Facques Derrida, edited by Giovanna Borradori, 83-136. Chicago: University of Chicago Press, 2003.

Derrida, Jacques. "Before the Law." Translated by Avital Ronell In Acts of Literature, edited by Derek Attridge, 183-219. New York: Routledge, 1992.

Derrida, Jacques. Demeure: Fiction and Testimony. Translated by Elizabeth Rottenberg. Stanford: Stanford University Press, 2000.

Derrida, Jacques. "Faith and Knowledge: The Two Sources of "Religion" at the Limits of Reason Alone." Translated by Samuel Weber In Religion, edited by Jacques Derrida and Gianni Vattimo, 1-78. Cambridge: Polity, 1998.

Derrida, Jacques. "Fifty-two Aphorisms for a Foreword." Translated by Andrew Benjamin In Psyche: Inventions of the Other, Volume II, edited by Peggy Kamuf and Elizabeth Rottenberg, 117-126. Stanford: Stanford University Press, 2008.

Derrida, Jacques. "Foi et savoir. Les deux sources de la "religion" aux limites de la simple raison." La religion. Séminaire de Capri sous la direction de Jacques Derrida et Gianni Vattimo, 9-86. Paris: Seuil, 1996. 
Derrida, Jacques. "Force of Law: The "Mystical Foundation of Authority."."Translated by Mary Quaintance Acts of Religion. edited and with an introduction \&il Anidjar, 230-298. New York: Routledge, 2002.

Derrida, Jacques. "Fors: The Anglish Words of Nicolas Abraham and Maria Torok." Translated by Barbara Johnson Nicolas Abraham and Maria Torok, The Wolf Man's Magic Word: A Cryptonymy. Translated by Nicholas Rand, Foreword by Jacques Derrida, xi-xiviii. Minneapolis: University of Minnesota Press, 1986.

Derrida, Jacques. Geneses, Genealogies, Genres, and Geniuses: The Secrets of the Archive. Translated by Beverley Bie Brahic. New York: Columbia University Press, 2006.

Derrida, Jacques. H. C. for Life, That Is to Say.... Translated, with additional notes, by Laurent Milesi and Stefan Herbrechter. Stanford: Stanford University Press, 2006.

Derrida, Jacques. "Heidegger's Hand (Geschlecht II)." Translated by John P. Leavey Jr. and Elizabeth Rottenberg In Psyche: Inventions of the Other, Volume II, edited by Peggy Kamuf and Elizabeth Rottenberg, 27-62. Stanford: Stanford University Press, 2008.

Derrida, Jacques. "Hostipitality." Translated by Barry Stocker and Forbes Morlock Angelaki 5, no. 3 (2000): 3-19.

Derrida, Jacques. "How to Avoid Speaking: Denials." Translated by Ken Frieden and Elizabeth Rottenberg In Psyche: Inventions of the Other, Volume II, edited by Peggy Kamuf and Elizabeth Rottenberg, 143-195. Stanford: Stanford University Press, 2008.

Derrida, Jacques. Khôra. Paris: Galilée, 1993.

Derrida, Jacques. "Khora." Translated by Ian McLeod In On the Name, edited by Thomas Dutoit, 89-127. Stanford: Stanford University Press, 1995.

Derrida, Jacques. Le toucher, Fean-Luc Nancy. Paris: Galilée, 2000.

Derrida, Jacques. Margins of Philosophy. Translated, with Additional Notes, by Alan Bass. Brighton: Harvester, 1982.

Derrida, Jacques. "Marx \& Sons." Translated by G.M. Goshgarian ${ }_{\perp}$ Ghostly Demarcations: A Symposium on Facques Derrida's 'Specters of Marx"' edited and introduced by Michael Sprinker, 213-269. London: Verso, 1999.

Derrida, Jacques. Monolingualism of the Other; or, The Prosthesis of Origins. Translated by Patrick Mensah. Stanford: Stanford University Press, 1998.

Derrida, Jacques. Negotiations: Interventions and Interviews, 1971=2001. Edited, Translated, and with an Introduction by Elizabeth Rottenberg. Stanford: Stanford University Press, 2001.

Derrida, Jacques. "No (Point of) Madness = Maintaining Architecture.” Translated by Kate Linker In Psyche: Inventions of the Other, Volume II, edited by Peggy Kamuf and Elizabeth Rottenberg, 87-103. Stanford: Stanford University Press, 2008.

Derrida, Jacques. Of Grammatology. Corrected edition. Translated by Gayatri Chakravorty Spivak. Baltimore: Johns Hopkins University Press, 1997.

Derrida, Jacques. Of Hospitality / Anne Dufourmantelle Invites Facques Derrida to Respond. Translated by Rachel Bowlby. Stanford: Stanford University Press, 2000.

Derrida, Jacques. On Touching $=$ Jean-Luc Nancy. Translated by Christine Irizarry. Stanford: Stanford University Press, 2005.

Derrida, Jacques. Points ... Interviews, 1974-1994. Translated by Peggy Kamuf et al., edited by Elisabeth Weber. Stanford: Stanford University Press, 1995.

Derrida, Jacques. Psyche. Inventions de l'autre. Paris: Galilée, 1987.

Derrida, Jacques. Rogues: Two Essays on Reason. Translated by Pascale-Anne Brault and Michael Naas. Stanford: Stanford University Press, 2005.

Derrida, Jacques. Specters of Marx: The State of the Debt, the Work of Mourning, and the New International. Translated by Peggy Kamuf. Introduction by Bernd Magnus and Stephen Cullenberg. New York: Routledge, 1994.

Derrida, Jacques. Speech and Phenomena, and Other Essays on Husserl's Theory of Signs. Translated, with an Introduction, by David B. Allison. Preface by Newton Garver. Evanston: Northwestern University Press, 1973.

Derrida, Jacques. The Beast and the Sovereign, Volume I. Translated by Geoffrey Bennington. Chicago: University of Chicago Press, 2009.

Derrida, Jacques. The Gift of Death. Translated by David Wills. Chicago: University of Chicago Press, 1995.

Milesi 
Derrida, Jacques. The Post Card: From Socrates to Freud and Beyond. Translated, introduction and additional notes by Alan Bass. Chicago: University of Chicago Press, 1987.

Derrida, Jacques. “"This Strange Institution Called Literature:” An Interview with Jacques Derrida." Translated by Geoffrey Bennington and Rachel Bowlby In Acts of Literature, edited by Derek Attridge, 33-75. New York: Routledge, 1992.

Derrida, Jacques, and Maurizio Ferraris. A Taste for the Secret. Translated by Giacomo Donis, edited by Giacomo Donis and David Webb. Cambridge: Polity, 2001.

Hägglund, Martin. Radical Atheism: Derrida and the Time of Life. Stanford: Stanford University Press, 2008.

Hägglund, Martin. "The Challenge of Radical Atheism: A Response." The New Centennial Review 9, no. 1 (2009): 227-252.

Hägglund, Martin. "The Non-Ethical Opening of Ethics: A Response to Derek Attridge." Derrida Today 3, no. 2 (2010): 295-305.

Hägglund, Martin. "The Radical Evil of Deconstruction: A Reply to John Caputo." Journal for Cultural and Religious Theory 11, no. 2 (2011): 126-150.

Hägglund, Martin. "Time, Desire, Politics: A Reply to Ernesto Laclau.” Diacritics 38, no. 1-2 (2008): 190-199.

Howells, Christina. Derrida: Deconstruction from Phenomenology to Ethics. Cambridge: Polity, 1999.

Khatib, Sami. "Derrida \& Sons: Marx, Benjamin, and the Specter of the Messianic." http:// anthropologicalmaterialism.hypotheses.org/1810

Laclau, Ernesto. "Is Radical Atheism a Good Name for Deconstruction?” Diacritics 38, no. 1 2 (2008): $180-189$.

Levinas, Emmanuel. Proper Names. Translated by Michael B. Smith. Stanford: Stanford University Press, 1996.

Levine, Michael G. A Weak Messianic Power: Figures of a Time to Come in Benjamin, Derrida, and Celan. New York: Fordham University Press, 2014.

Milesi, Laurent. "Portrait of H.C. as J.D. and Back." New Literary History 37, no. 1 (2006): $65-84$.

Milesi, Laurent. "Semiology and Deconstruction: From Sign to Trace." In Managing Global Communications. Proceedings of the 2nd ROASS Conference, edited by Doina Cmeciu and Traian D. Stănciulescu, 135-146. Bacău: Alma Mater, 2009.

Milesi, Laurent. "Thinking (Through) the Desert (la pensée du désert) ith(in) Jacques Derrida." In The Politics of Deconstruction: Facques Derrida and the Other of Philosophy, edited by Martin McQuillan, 173-191. London: Pluto, 2007.

Miller, J. Hillis. "Derrida's Topographies." Chap. 11 in Topographies. Stanford: Stanford University Press, 1995.

Miller, J. Hillis. For Derrida. New York: Fordham University Press, 2009.

Papadakis, Andreas, Catherine Cooke, and Andrew Benjamin, eds. Deconstruction Omnibus Volume. London: Academy Editions, 1990.

Srajek, Martin C. In the Margins of Deconstruction. Fewish Conceptions of Ethics in Emmanuel Levinas and Jacques Derrida. Dordrecht: Springer, 1998.

The New Centennial Review. 9, no. 1: 'Living On: Of Martin Hägglund.' 2009.

Vitale, Francesco. "Jacques Derrida and the Politics of Architecture." Serbian Architectural Fournal 2, no. 3 (2010): 215-226.

Vitale, Francesco. "The Law of the Oikos. Jacques Derrida and the Deconstruction of the Dwelling." Serbian Architectural Fournal 5, no. 1 (2013): 59-74.

Ware, Owen. "Dialectic of the Past / Disjuncture of the Future: Derrida and Benjamin on the Concept of Messianism." Fournal for Cultural and Religious Theory 5, no. 2 (2004): 99-114.

Laurent Milesi is Chair of the Centre for Critical and Cultural Theory at Cardiff University, where he also teaches 20th-Gentury English/American Literature, and is a member of the ITEM-CNRS Research Group on James Joyce's manuscripts in Paris. He has written numerous essays on Joyce and related aspects of modernism, 19th- and 20th-century (American) poetry, postmodernism and poststructuralism, 
TPAR 988908-5/1/2015-SATHISHKUMAR.K-500448-Own Style

913 with a particular emphasis on Jacques Derrida and Hélène Cixous. Aside from 914 several other translation projects related to Derrida's and Cixous's works, he is 915 completing a monograph on the sense of '(non-)place' in Derrida. Email: 916 senlpm@cf.ac.uk

917

918

919

920

921

922

923

924

925

926

927

928

929

930

931

932

933

934

935

936

937

938

939

940

941

942

943

944

945

946

947

948

949

950

951

952

953

954

955

956

957

958

959

960

Milesi 